INVESTIGACIÓN

\title{
Evaluation of two-different affinity chromatographic columns based on Protein A for the purification of an IgG2a monoclonal antibody from ascites.
}

\author{
Evaluación de dos columnas cromatográficas de afinidad diferentes basadas \\ en la Proteína A para la purificación de un anticuerpo monoclonal IgG2a de \\ ascitis.
}

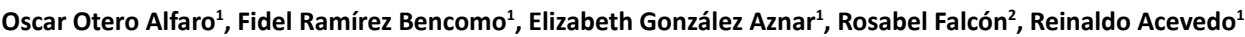

DOI. 10.21931/RB/2017.02.02.5

\section{ABSTRACT}

Purification of monoclonal antibodies (MAbs) is today a routine procedure in laboratories destined for obtaining these molecules. Several approaches, based mainly on differential solubility and chromatographic methods, are frequently used for reaching the purity required of these products. For IgG MAbs, affinity chromatography using immobilized protein $A$ or $G$, is frequently the best option to perform a purification protocol in a single step. In our laboratory, the purification of MAbs like 7E1F7 (IgG2a) against capsular polysaccharide from Neisseria meningitidis serogroup A, are usually done by affinity chromatography on Protein G. The objective of this work was to evaluate the feasibility to use two-different affinity chromatographic columns based on Protein A (HiTrap from GE and CIM-A from BIA Separations), for the purification of this MAb. The same purification protocol was followed with both columns. Percentage of recovery, purity and immunoreactivity of the purified MAb were calculated and used to compare the performance of both columns. Similar chromatographic profiles were obtained from both columns. However, for CIM-A column, protein concentration and total recovery were significantly higher $(p<0.0001)$. Purity levels of the 7E1F7 MAb over $95 \%$ was obtained with both columns without any change on its immunoreactivity. The use of Protein A coupled to monolith supports, like from BIA Separations Company, offers an attractive possibility to purify MAbs from ascites with high recovery, purity levels and fully preserved reactivity. This paper constitutes the first report on the use of monolithic columns in the purification of monoclonal antibodies from ascites.

Keywords: Monoclonal Antibodies, Ascites, Protein A, Particle Bed, Monolith, and Affinity Chromatography.

\section{RESUMEN}

La purificación de anticuerpos monoclonales (MAb) es hoy un procedimiento de rutina en laboratorios destinados a la obtención de estas moléculas. Para alcanzar la pureza requerida de estos productos se utilizan frecuentemente diversos enfoques, principalmente basados en el diferencial de solubilidad y en métodos cromatográficos. Para los MAbs de tipo IgG, la cromatografía de afinidad utilizando la proteína A o G inmovilizada, es frecuentemente la mejor opción para realizar un protocolo de purificación en un solo paso. En nuestro laboratorio, la purificación de MAbs como el 7E1F7 (IgG2a) específico a polisacárido capsular de Neisseria meningitidis serogrupo A se realiza habitualmente por cromatografía de afinidad utilizando proteína G. El objetivo de este trabajo fue evaluar la viabilidad de utilizar dos columnas cromatográficas diferentes de afinidad basadas en Proteína A (HiTrap de GE y CIM-A de BIA Separations), para la purificación de este MAb. Se siguió el mismo protocolo de purificación con ambas columnas. Se calculó el porcentaje de recuperación, pureza e inmunoreactividad del MAb purificado para comparar el rendimiento de ambas columnas. Se obtuvieron perfiles cromatográficos similares de ambas columnas. Sin embargo, para la columna CIM-A, la concentración de proteínas y la recuperación total fueron significativamente mayores ( $p$ $<0,0001)$. Se obtuvieron altos niveles de pureza del MAb 7E1F7, superiores al $95 \%$ con ambas columnas, sin ningún cambio en su inmunorreactividad. El uso de Proteína A acoplada a soportes monolíticos, como los de BIA Separations, ofrece una posibilidad atractiva para purificar MAbs de ascitis con alta recuperación, niveles de pureza y reactividad totalmente preservada. Este documento constituye el primer informe sobre el uso de columnas monolíticas en la purificación de anticuerpos monoclonales a partir de líquido ascítico.

Palabras claves: Anticuerpos Monoclonales, Líquido Ascitico, Proteina A, Lecho de partículas, Monolito y Cromatografía de Afinidad

\section{Introducción}

The diversity of the antibody-antigen interaction and the possibility to manipulate its characteristics, have created many uses for antibodies and antibody fragments, both for immunochemical techniques within general research and for therapeutic and diagnostic applications. A new age was born for the science, when Kohler and Milstein ${ }^{1}$ described the obtaining of monoclonal antibodies (MAbs) by mean of cellular fusion. Since then, different methods have been developed to purify these molecules. Proceedings based on the principle of differential solubility like: salting out (ammonium or sodium sulfate), caprylic acid or solvent addition, among others, are still used for isolation of fractions containing antibodies. These protocols are

${ }^{1}$ Monoclonal Antibodies Laboratory, Department of Biological Evaluation, Research Area, Institute of Vaccines Finlay. Havana, Cuba,

${ }^{2}$ Department of Microbiology, IPK, Havana, Cuba

Correspondence: framirez@finlay.edu.cu 
suitable for bulk proteins and when high purity is not necessary. Chromatographic methods based on anion or cation exchange, hydrophobic interaction, affinity and multi-step-strategies are usually used for reaching purer products ${ }^{2,3}$.

Many of generated MAbs belong to IgG class and in this regard, affinity chromatography using immobilized protein $\mathrm{A}$ is the most applied affinity system for the purification of antibodies in a single step ${ }^{4}$.Different supports have been used for covalent coupling, either Protein A, G or both ${ }^{4-7}$. During more than 40 years, particulate chromatographic supports (beads) have been widely applied in affinity chromatography ${ }^{8,9}$. Chromatographic monoliths have arisen as an alternative stationary phase having some distinct advantages over beads, which could be summarized as:

\section{Very high porosity}

High binding capacity for extremely large molecules

Mass transport based on convection ${ }^{10}$

Chromatographic monoliths can bear any chemical functionality and as such, they can be implemented for various analysis or purifications, one of them being protein A-based chromatography ${ }^{11,12}$.

Our work team previously obtained an IgG2a MAb named 7E1F7 against the capsular polysaccharide of Neisseria meningitidis serogroup A $(\mathrm{CPA})^{13}$. The purification of this MAb from ascites, was carried out by affinity chromatography on HiTrap Protein G (GE Healthcare, USA) according to the manufacturer's procedure. Several analytical assays, using purified 7E1F7 MAb, such as identity test by indirect ELISA and quantitation of CPA by Sandwich ELISA have been employed ${ }^{13,14}$.

In this report, we compared two-different affinity chromatography columns based on Protein A for the 7E1F7 MAb purification from ascites, in order to explore new methodologies that improves total recovery of the process. The columns: HiTrap rProtein A FF (1 mL) from GE (USA) and CIM r-Protein A-1 (1 $\mathrm{mL}$ ) from BIA Separations (Slovenia), were evaluated at the same chromatographic conditions.

\section{MATERIALS AND METHODS}

\section{Affinity Columns:}

-HiTrap rProtein A FF (1ml) from GE, USA (HiTrap A), product code 17-5079-02. Support based on particle media Sepharose Fast Flow.

-CIM r-Protein A-1 (1 mL) monolithic chromatographic support from BIA Separations, Slovenia (CIM A), and product code 317.1004.

\section{Other reagents:}

-Capsular polysaccharide from Neisseria meningitidis serogroup A (CPA): MenA PACI lot [2]/10 provided by the Department of Reference Materials of "Finlay Institute", Cuba.

-Ascites containing the 7E1F7 MAb (IgG2a subclass) provided by Monoclonal Antibody Laboratory, "Finlay Institute", Cuba.

All chemical reagents and anti-mouse IgG/HRP conjugated were purchased from Sigma, USA.

\section{Sample preparation}

Six milliliters of ascites containing the 7E1F7 MAb (IgG2a subclass) were two-fold diluted in phosphate buffered saline, $\mathrm{pH}$ 7.4 (PBS) to a final volume of $12 \mathrm{~mL}$. The sample was clarified using a MiniSart $0.2 \mu \mathrm{m}$ filter (Sartorius AG, Germany) and divided into two aliquots of $6 \mathrm{~mL}$ each.

\section{Purification of 7E1F7 MAb by affinity chromatogra- phy using two different columns}

Chromatographic experiments were performed using AKTA FPLC System and UNICORN software version 3.0 (GE, USA) for data acquirement. The same experimental procedure was followed for both affinity columns. The flow rate applied in all steps was $1 \mathrm{~mL} / \mathrm{min}$. Previous column equilibration with $10 \mathrm{~mL}$ of PBS, an aliquot of $6 \mathrm{~mL}$ was loaded into a Superloop and was injected in three individual runs of $2 \mathrm{~mL}$ each. After washing with $10 \mathrm{~mL}$ of PBS, the unbound fraction (U.F) was collected from the peak start to the end. Desorption of the specific fraction (S.F) containing the MAb, was carried out by acid elution with $10 \mathrm{~mL}$ of 0.1 $\mathrm{mol} / \mathrm{L}$ citric acid solution, pH 5.0 adjusted with sodium hydroxide. The S.F was collected like above and neutralized with Tris $1 \mathrm{~mol} / \mathrm{L}, \mathrm{pH}$ 8.0. The elution volume of each fraction was recorded. Regeneration step after each purification cycle was carried out by flushing $10 \mathrm{~mL}$ of $0.1 \mathrm{~mol} / \mathrm{L}$ citric acid solution adjusted to $\mathrm{pH}$ 3.0, followed by immediately re-equilibration of the columns with PBS pH 7.4.

\section{Estimation of total recovery}

Total protein concentration in S.F from each run was quantified by the bicinchoninic acid reaction ${ }^{15}$ using the Bicinchoninic Acid Protein Assay Kit from Sigma, USA and Bovine Serum Albumin (BSA) as standard. Each sample was assayed in triplicate with appropriated dilutions for fixing to the standard curve. Total recovery of purified 7E1F7 MAb from each run, was estimated and expressed as milligrams of MAb per milliliter of ascites.

\section{Analysis of the fractions by SDS-PAGE}

From both chromatographic experiments, ascites (1:20), U.F (1:10) and S.F ( $5 \mu \mathrm{g} / \mathrm{lane})$ were analyzed on a $12.5 \%$ SDS-PAGE under reducing conditions following the Laemmli procedure ${ }^{16}$. The bands were visualized using Blue Coomassie R-250 staining. A molecular weight ladder from 97 to $14.4 \mathrm{KDa}$ (GE, USA) was used to estimate the molecular weight of the resolved proteins. Densitometry analysis was performed by mean of Quantity One software (Bio-Rad, USA) for purity estimation.

\section{Immunoreactivity of the purified MAb}

In order to evaluate the reactivity of the purified 7E1F7 MAb, an indirect ELISA was carried out as follow. Maxisorp (NUNC, Denmark) plate was coated with $100 \mu \mathrm{l} /$ well of CPA at $10 \mu \mathrm{g} / \mathrm{mL}$ in PBS pH 7.4 for $16 \mathrm{~h}$ at $4^{\circ} \mathrm{C}$. After three washes with PBS containing $0.5 \%$ Tween $20,250 \mu \mathrm{L} /$ well of blocking solution (PBS, $3 \%$ skimmed milk) was added and incubated for $1 \mathrm{~h}$ at $37^{\circ} \mathrm{C}$. Excess of blocking solution was removed in a washing step and duplicated samples (100 $\mu \mathrm{L} /$ wells) of purified 7E1F7 MAb from each S.F were added in two-fold dilutions from $1000 \mathrm{ng} / \mathrm{mL}$ to $15 \mathrm{ng} / \mathrm{mL}$ in PBS. The same buffer was used as blank. The plate was incubated for $2 \mathrm{~h}$ at $37^{\circ} \mathrm{C}$. After three washes and addition of anti-mouse IgG/HRP conjugated diluted 1:1000 in PBS $(100 \mu \mathrm{L} /$ wells), the reaction was incubated for $1 \mathrm{~h}$ at room temperature. Then, last four washing cycle was performed and $\mathrm{OPD} / \mathrm{H} 2 \mathrm{O} 2$ substrate was added. After $30 \mathrm{~min}$, the reaction was stopped with $50 \mu \mathrm{L} /$ well of $2 \mathrm{M} \mathrm{H} 2 \mathrm{SO} 4$ and absorbance was read in a Multiskan Microplate Reader (ThermoScientific, USA).

\section{Statistical Analysis}

Data were analyzed using Graph Pad Prism 5 software (California, USA). Statistical significance between group mean values was analyzed by a Student's 2-tailed t test for two groups (HiTrap A vs CIM A columns). Differences were considered significant when $p<0.05$. For statistical analysis of the immunoreactivity assay results, a 2-way ANOVA comparison test was performed. Data are expressed as the mean optical density (OD) of samples (three runs) measured at $492 \mathrm{~nm}$ plus standard deviation of three independent experiments. 


\section{RESULTS}

Identical procedures were used for either HiTrap A or CIM A columns. Figure 1 shows the chromatographic profiles obtained from three runs performed on each column. The U.F in each column were eluted in $4.5 \mathrm{~mL}$ for HiTrap A and $4 \mathrm{~mL}$ for CIM A, while S.F were eluted in $4 \mathrm{~mL}$ and $2.5 \mathrm{~mL}$ respectively.

Figure 2 shows the analysis of all fractions obtained from each running. No significant variation in the volume of U.F was found between the HiTrap A and CIM A, while the volume corresponding to the S.F containing the 7E1F7 MAb was dramatically reduced in CIM A column and significant differences were found $(\mathrm{p}<0.005)$.

The mean of the estimated protein concentration in S.F was $0.463 \mathrm{mg} / \mathrm{mL}$ for HiTrap A and $0.915 \mathrm{mg} / \mathrm{mL}$ for CIM A column, while the mean of the total recovery was $1.853 \mathrm{mg}$ and $2.287 \mathrm{mg}$ per $\mathrm{mL}$ of ascites respectively. Statistical analysis showed significant differences between both columns (Figure 3).
Chromatographic fractions were run on a $12.5 \%$ SDS-PAGE under reducing conditions (Figure 4). Corresponding bands to heavy chain $(50 \mathrm{KDa})$ and light chain $(25 \mathrm{KDa})$ were identified in all S.F tracks. An additional band with MW of $66 \mathrm{KDa}$ approximately was recorded in all S.F eluted from the HiTrap A column, which might be probably albumin.

The densitometric analysis (Table 1) showed that purity of the MAb obtained from CIM A column was over $99 \%$ while using HiTrap A column it was $95.5 \%$. Low coefficient of variation $(\mathrm{CV}<5 \%)$ was obtained between the three runs performed in each column.

Immunoreactivity of the purified 7E1F7 MAb was evaluated in an indirect ELISA. The S.F from each run preserved its reactivity in all cases. No significant differences were noticed when the data were analyzed by the 2-way ANOVA. Results and statistical analysis of this assay are showed in Figure 5. The optical densities obtained from the lower concentration $(15 \mu \mathrm{g} / \mathrm{mL})$ were three times over than the PBS blank.

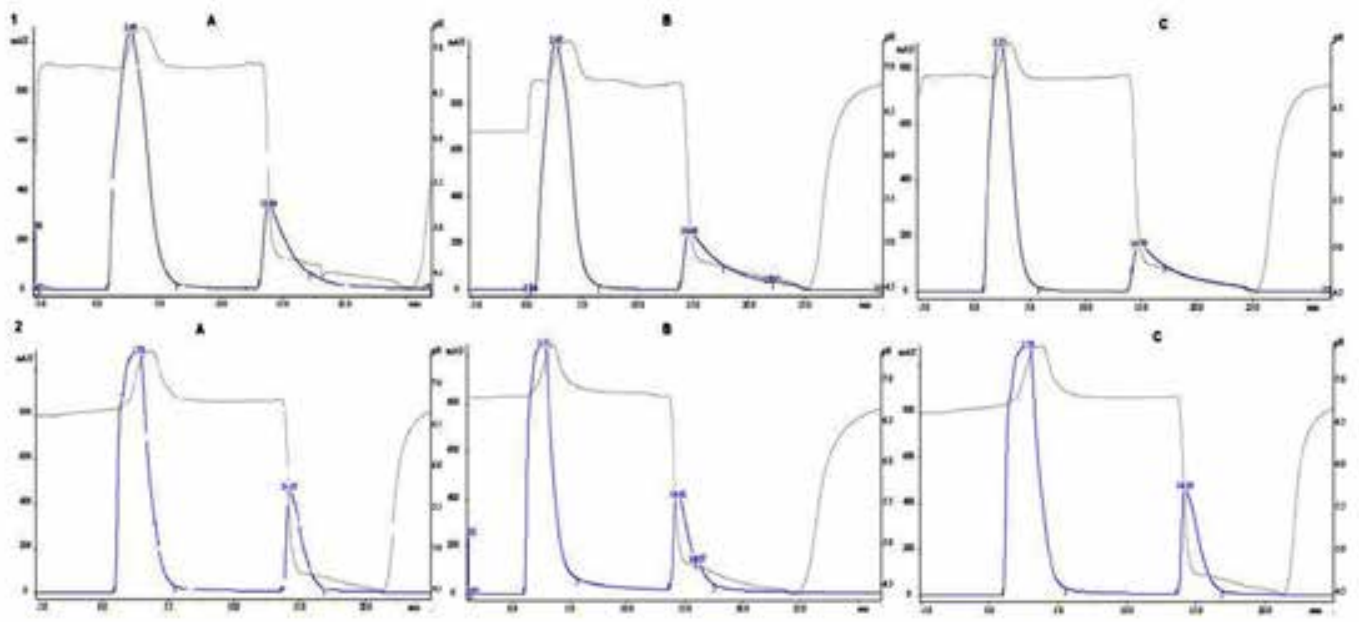

Figura 1: Chromatographic profiles (A, B and C) obtained from affinity column HiTrap A (1) and CIM A (2). Sample injected: $2 \mathrm{~mL}$ of ascites containing 7E1F7 MAb (1/2 in PBS). SF: eluted with $0.1 \mathrm{~mol} / \mathrm{L}$ citric acid, pH 5.0

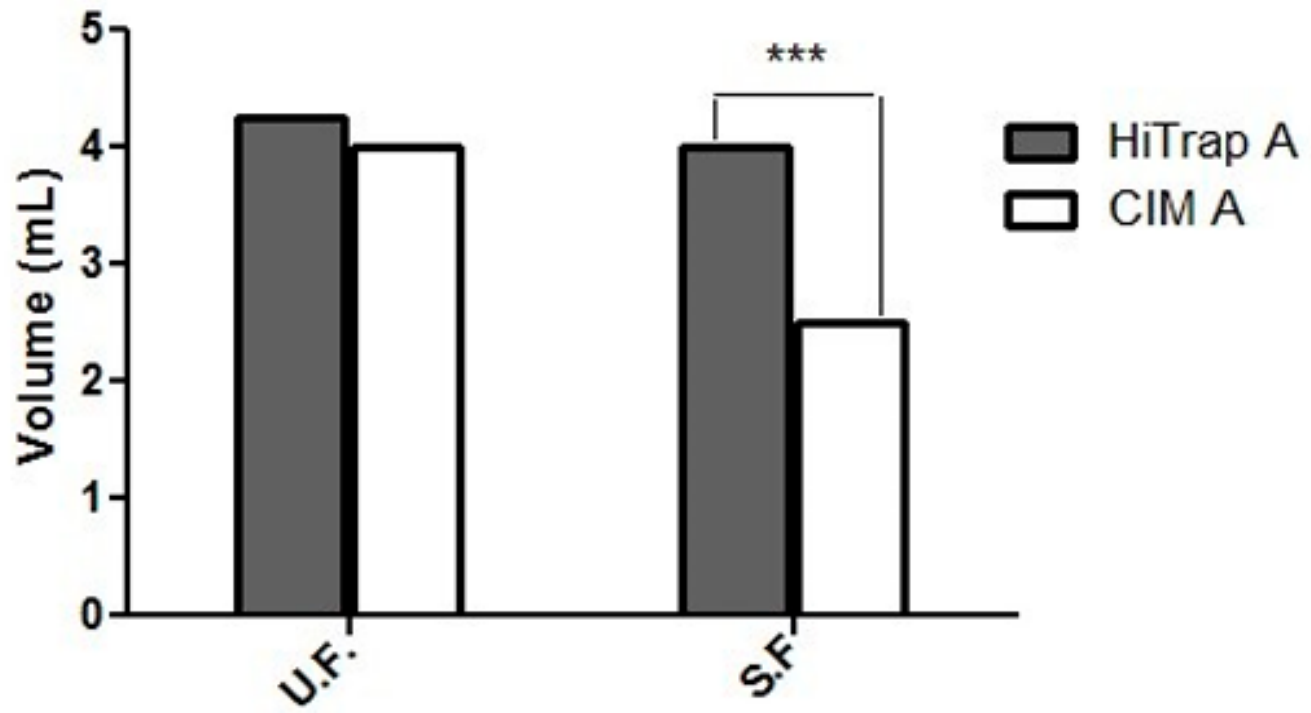

Figura 2: Comparison between the volume of U.F and S.F obtained from each affinity column (HiTrap A and CIM A). Data are expressed as the mean from three independent experiments. Significant differences between the means of the two groups (HiTrap A and CIM A) were determined by a Student's 2-tailed t test using the Graph Pad Prism 5 software (California). ${ }^{* * *}$ Statistically significant at $\mathrm{p}<0.005$. 
A

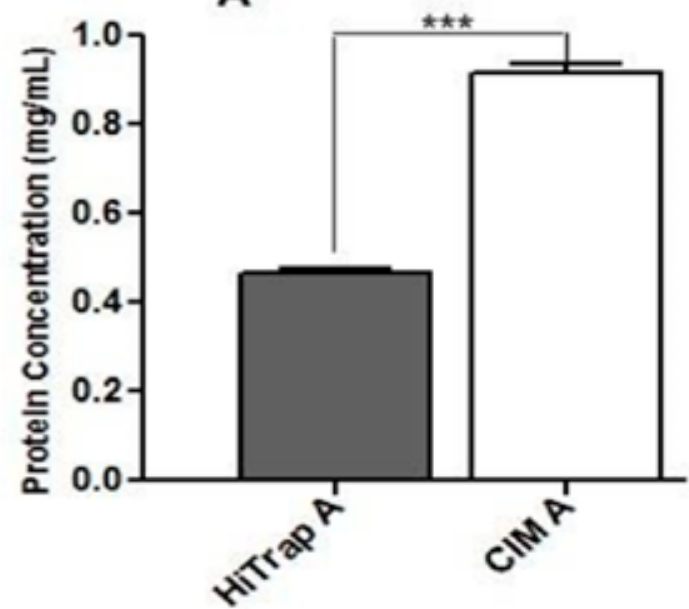

B

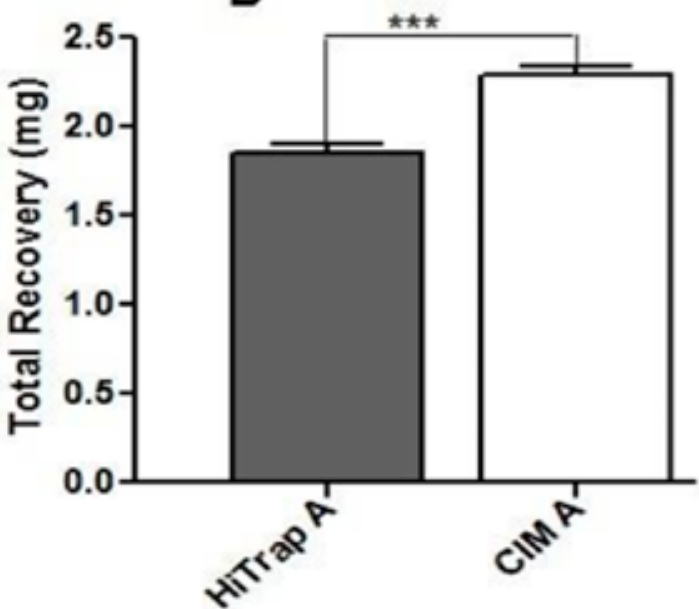

Figura 3: Comparison between Protein Concentration (A) and total recovery (B) in the S.F obtained from each affinity column (HiTrap A and CIM A). Data are expressed as the mean from three independent experiments. Significant differences between the means of the two groups (HiTrap A and CIM A) were determined by a Student's 2-tailed t test using the Graph Pad Prism 5 software (California). ${ }^{* * *}$ Statistically significant at $\mathrm{p}<0.005$.

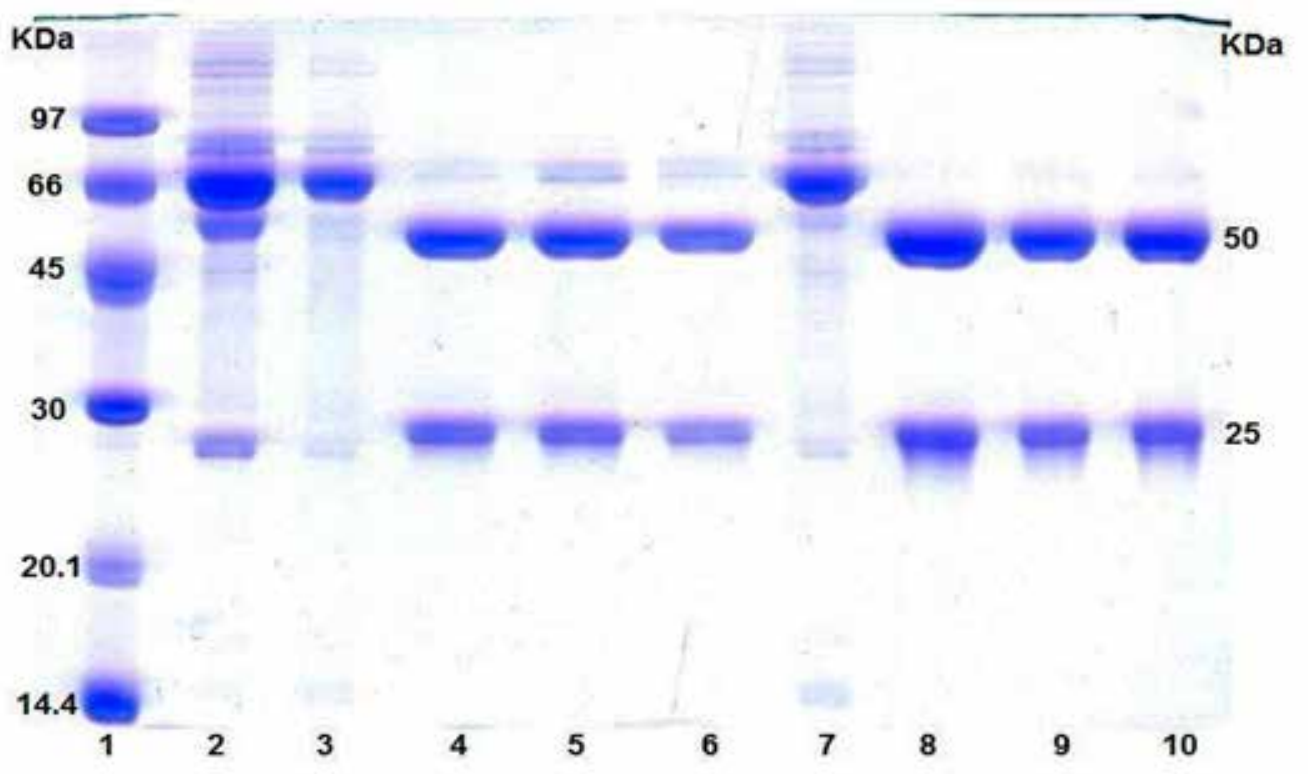

Figura 4: SDS-PAGE under reducing conditions on $12.5 \%$ resolving gel. Electrophoretic profile of each fraction involved in the purification process using both affinity columns, HiTrap A (line 3 through 6) and CIM A (line 7 through 10). Lane 1: molecular ladder, Lane 2: ascites. Lanes 3 and 7: U.F. Remaining lanes $(4,5,6,8,9$ and 10$)$ : S.F from 3 runs performed in each affinity column

\begin{tabular}{|c|c|c|c|c|c|}
\hline Column employed & Runs & Percent Purity (\%) & Mean & SD & CV $\%$ \\
\hline \multirow{3}{*}{ HiTrap A } & Run 1 & 96.78 & \multirow{4}{*}{95.51} & \multirow{4}{*}{2.14} & \multirow{4}{*}{2.24} \\
\hline & Run 2 & 93.04 & & & \\
\hline & Run 3 & 96.7 & & & \\
\hline \multirow{3}{*}{ CIM A } & Run 1 & 99.46 & & & \\
\hline & Run 2 & 99.08 & \multirow[t]{2}{*}{99.23} & \multirow[t]{2}{*}{0.20} & \multirow[t]{2}{*}{0.20} \\
\hline & Run 3 & 99.15 & & & \\
\hline
\end{tabular}




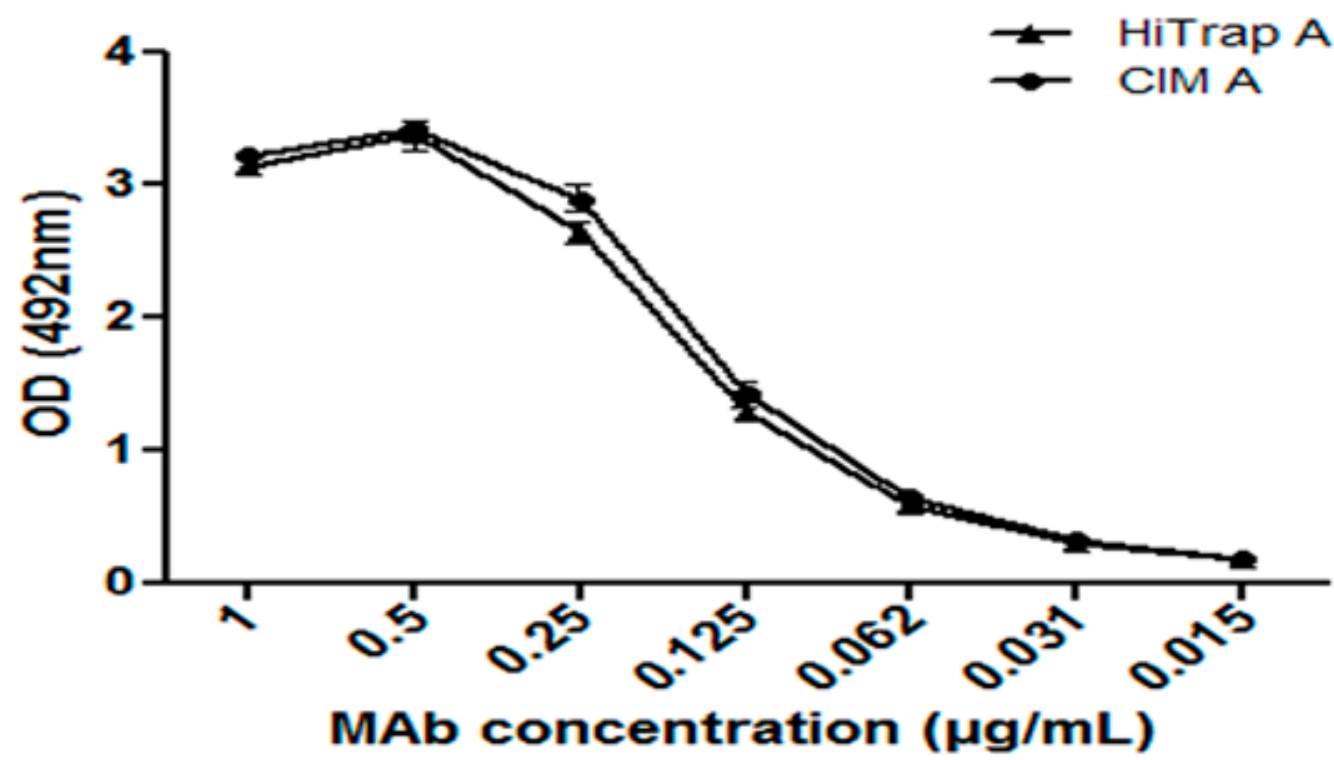

Figura 5: Reactivity of the purified MAb according to the affinity column used (HiTrap and CIM A), evaluated in an indirect ELISA. Data are expressed as the mean optical density (OD) of samples (3 runs) measured at $492 \mathrm{~nm}+$ standard deviation of three independent experiments. Significant differences between the means of different groups were determined by a 2-way ANOVA comparison test using the Graph Pad Prism 5 software (California).

\section{DISCUSSION}

Chromatography is a separation process based on the equilibrium between stationary and mobile phases. In chromatographic supports based on individual particles (beads), like Sepharose, the hydrodynamic behavior is well defined by Van Deemter equation ${ }^{17,18}$. Particle size and distribution, flow rate and diffusion are parameters that affect the resolution in this kind of support ${ }^{19}$. In contrast, monolith supports results in a unique piece as solid phase with a macroporous inner structure. The main features that determine the performance of any stationary phase for chromatography in flat monolithic disks are the surface chemistry, which determines the interaction of the analytes, and the pore size (distribution), which determines mass transfer and hydrodynamic behavior $^{20}$. Increased mass transfer, rapid equilibrium and high adsorption capacity lead to rapid and high- resolution separations $^{11,12}$. In this sense, CIM A column showed smaller elution volumes in U.F and S.F compared with HiTrap A column (Fig. 1). In addition, higher IgG adsorption was obtained too. Usually in our lab, with the traditional purification method using HiTrap G column $^{13}$, the recovery of MAb purified is around $1.5 \mathrm{mg}$ of MAb/ $\mathrm{mL}$ of ascites (data no published) and using either HiTrap A or CIM A columns better results were obtained.

Protein A and protein G are bacterial proteins from Staphylococcus aureus and Streptococcus respectively, which naturally interacts with the Fc $\gamma$ fragment of antibodies. This feature makes them extremely useful selective ligands, for several routine applications. Examples include the purification of monoclonal, polyclonal IgG-type antibodies and its subclasses, and the adsorption and purification of immune complexes involving IgG. IgG subclasses can be isolated from ascites, cell culture supernatants and serum ${ }^{4,21}$. Another important factor to consider in affinity chromatography is the material used to hold the ligand within the column. Ideally, supports should have low nonspecific binding for sample components, it should be easy to modify for ligand attachment, and it should be stable under the flow-rate, pressure, and solvent conditions that will be employed in the analysis or purification of samples 9 . In this respect, the two-media used (HiTrap A and CIM A) met with this requirement. Purity levels over $95.5 \%$ were estimated by densitometry for both columns and this is enough for the intended use of this MAb in our lab.

The reactivity of the purified 7E1F7 MAb in all S.F was fully preserved after the purification step. Isotype IgG2a elutes from protein $\mathrm{A}$ at $\mathrm{pH}$ value nearly to $5.0^{22}$ therefore, the use of protein A as ligand, avoids the extreme drastic elution ( $\mathrm{pH}$ 2.7) used in protein $\mathrm{G}$ that often cause protein denaturation. The purification of MAbs from ascites using protein A linked to conventional particle bed (HiTrap A) is very well documented ${ }^{23}$ but to our knowledge, there are none reports for monolith columns like CIM A. However, many MAbs have been purified from cell supernatant using this technology ${ }^{24}$. The use of protein A coupled to monolith supports, as the BIA Separations Company, offers an attractive alternative to purify MAbs from ascites with high recovery and purity levels and fully preserved reactivity. This paper constitutes the first report on the use of monolithic columns in the purification of monoclonal antibodies from ascites.

\section{References}

1. Kohler G, Milstein C. Continuous cultures of fused cells secreting antibody of predefined specificity. Nature. 1975;256(5517):495-7.

2. Scopes RK. Protein purification: principles and practice / Robert K. Scopes. NewYork: Springer-Verlag; 1994.

3. Janson JC. Protein Purification: Principles, High Resolution Methods, and Applications: Wiley; 2012.

4. Hober S, Nord K, Linhult M. Protein A chromatography for antibody purification. Journal of Chromatography B. 2007;848(1):40-7.

5. Hou KC, Zaniewski R, Roy S. Protein A immobilized affinity cartridge for immunoglobulin purification. Biotechnology and applied biochemistry. 1991;13(2):257-68.

6. Boi C, Dimartino S, Sarti GC. Performance of a new protein A affinity membrane for the primary recovery of antibodies. Biotechnology progress. 2008;24(3):640-7.

7. Biedermann K, Sabater M, Sorensen J, Fiedler H, Emborg C. Quantitative binding studies of a monoclonal antibody to immobilized protein-A. Bioseparation. 1991;2(5):309-14.

8. Porath J, Aspberg K, Drevin H, Axén R. Preparation of cyanogen bromide- activated agarose gels. Journal of Chromatography A. 1973;86:53-6.

9. Hage DS. Affinity chromatography: a review of clinical applications. Clinical chemistry. 1999;45(5):593-615.

10. Podgornik A, Yamamoto S, Peterka M, Krajnc NL. Fast separation of large biomolecules using short monolithic columns. Journal of Chromatography B. 2013;927:80-9.

11. Josić D, Štrancar A. Application of Membranes and Compact, Porous Units for the Separation of Biopolymers. Industrial \& Engineering Chemistry Research. 1999;38(2):333-42.

12. Tennikova TB, Reusch J. Short monolithic beds: history and introduction to the field. Journal of Chromatography A. 2005;1065(1):13-7. 
13. Reyes F, Amin N, Otero O, Aguilar A, Cuello M, Valdés Y, et al. Four monoclonal antibodies against capsular polysaccharides of Neisseria meningitidis serogroups $\mathrm{A}, \mathrm{C}, \mathrm{Y}$ and W135: Its application in identity tests. Biologicals: journal of the International Association of Biological Standardization. 2013;41(4):275-8.

14. Reyes F, Otero O, Cuello M, Amin N, García L, Cardoso D, et al. Development of four sandwich ELISAs for quantitation of capsular polysaccharides from Neisseria meningitidis serogroups A, C, W and $\mathrm{Y}$ in multivalent vaccines. Journal of immunological methods. 2014;407:58-62.

15. Smith PK, Krohn RI, Hermanson GT, Mallia AK, Gartner FH, Provenzano MD, et al. Measurement of protein using bicinchoninic acid. Anal Biochem. 1985;150(1):76-85.

16. Laemmli UK. Cleavage of structural proteins during the assembly of the head of bacteriophage T4. Nature. 1970;227(5259):680-5.

17. Snyder LR, Kirkland JJ, Dolan JW. Introduction to Modern Liquid Chromatography: Wiley; 2011

18. Poole CF, Poole SK. Chromatography today1991. 1037-p.
19. Cazes J. Encyclopedia of Chromatography: Taylor \& Francis; 2005.

20. Hahn R, Panzer M, Hansen E, Mollerup J, Jungbauer A. Mass transfer properties of monoliths. Separation Science \& Technology. 2002;37(7):1545-65.

21. McCue JT, Kemp G, Low D, Quinones-Garcia I. Evaluation of protein-A chromatography media. Journal of chromatography A. 2003;989(1):139-53.

22. Healthcare GE. Antibody Purification Handbook2002-2015. 48- p.

23. Carlsson M, Heijbel A, Hiiggqvist A-C. Convenient Purification of Monoclonal Antibodies using HiTrap rProtein A FF. G. E. Healtcare, 2007.

24. Beerli RR, Bauer M, Schmitz N, Buser RB, Gwerder M, Muntwiler $\mathrm{S}$, et al. Prophylactic and therapeutic activity of fully human monoclonal antibodies directed against influenza A M2 protein. Virology journal. 2009;6:224.

Recibido: diciembre de 2016.

Aprobado: febrero de 2016.

\section{\#ClimateChange}

\section{WHO IS AT RISK OF CLIMATE CHANGE?}

Those living in poverty, as well as women, children and the elderly.
Outdoor workers and people living with chronic medical conditions.
Children are the most vulnerable due to long exposure to environmental risks.

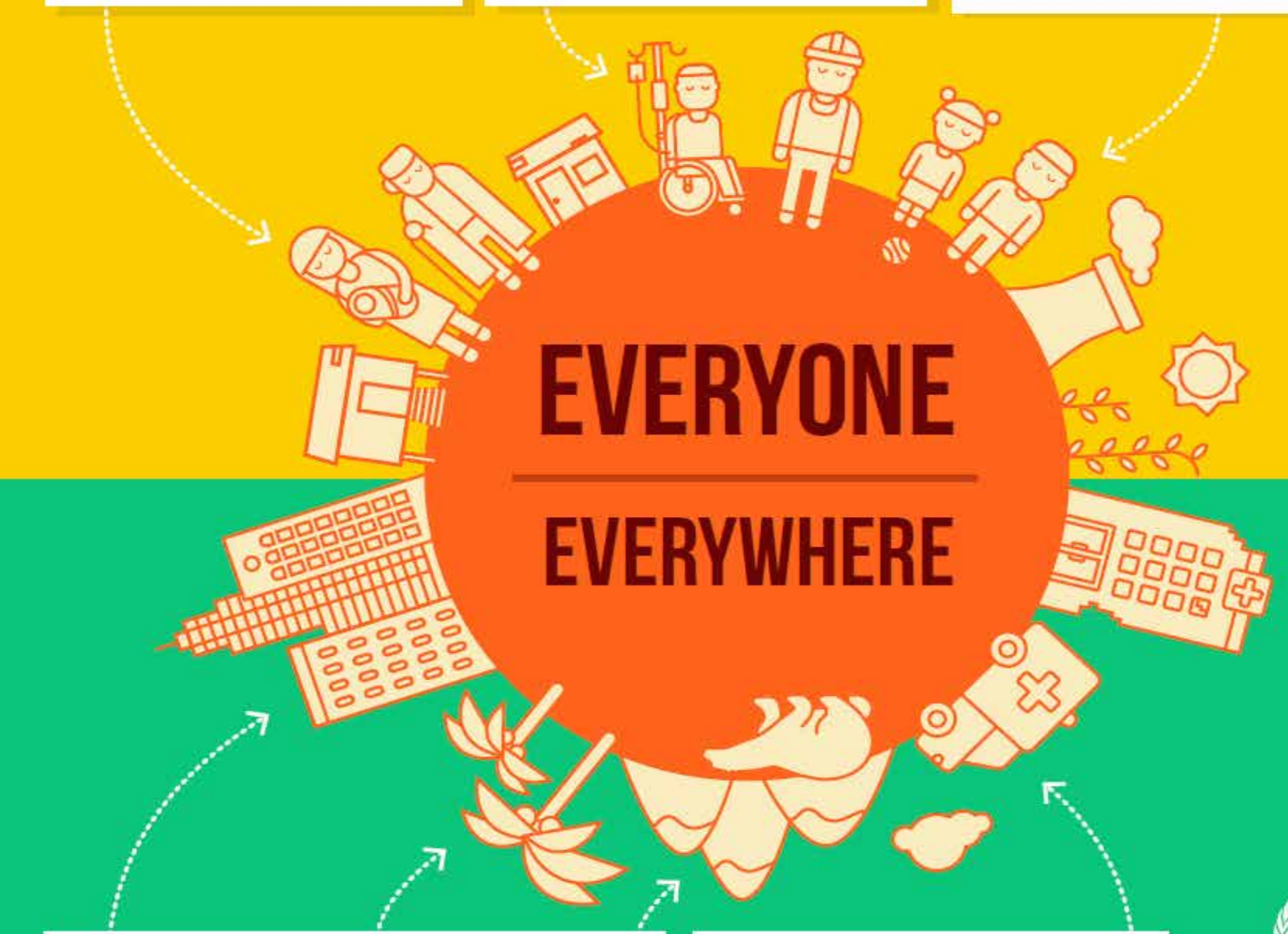

Those living in megacities, small island developing states and other coastal, mountainous and polar regions.

Countries with weak health systems will be least able to prepare and respond.

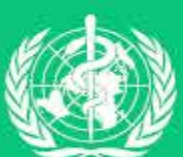

World Health Organization 